\title{
Modelling and Simulation of Waste Plastic Power Plant: A Theoretical Framework
}

\author{
Nsidibe-Obong Ekpe Moses", Collins Erhianoh, Christiana Edward Anih
}

Department of Chemical Engineering, Federal University of Petroleum Resources, Effurun, Nigeria

\section{Email address:}

moses.nsidibe@fupre.edu.ng (Nsidibe-Obong E. M.)

${ }^{*}$ Corresponding author

\section{To cite this article:}

Nsidibe-Obong Ekpe Moses, Collins Erhianoh, Christiana Edward Anih. Modelling and Simulation of Waste Plastic Power Plant: A Theoretical Framework. American Journal of Chemical Engineering. Vol. 6, No. 5, 2018, pp. 94-98. doi: 10.11648/j.ajche.20180605.13

Received: September 7, 2018; Accepted: September 25, 2018; Published: October 31, 2018

\begin{abstract}
The high energy content of plastics can be converted to electricity. The recovery of this abundant energy helps to curb environmental concerns associated with plastic utilization. Non-recyclable plastic materials are used in areas like packaging, 3D printing, and construction. Where recycling becomes an issue, technologies that utilize the waste plastics to generate electricity can be employed. This paper presents a theoretical framework for the simulation of waste plastic power plant. A simulation model that produces electricity from the High Density Polyethylene (HDPE) waste plastics has been developed using Aspen Hysys process simulator. The pyrolysis reactor modelled as a conversion reactor was used to thermally crack $2000 \mathrm{Kg} / \mathrm{h}$ of HDPE feed at a temperature of $450^{\circ} \mathrm{C}$ to produce a top product containing a mixture of liquid fuel oil and volatile gaseous fuel. After cooling of the top product and separation to obtain the volatile gaseous fuel from the liquid fuel oil, the volatile gaseous fuel alongside air were pressurized with a compressor and then combusted in a Gibbs free energy reactor. In this reactor, the gaseous fuel burned with excess air in the combustion chamber to produce a high temperature and pressured gas that drove the gas turbine (modelled as an expander) to generate electrical power of 1194KW. To achieve proper energy optimization, the high temperature flue gas obtained from the gas turbine after pressure loss was passed through a "Heat Recovery Steam Generator" that allowed water at $25^{\circ} \mathrm{C}$ to be heated up to produce steam which in turn drove a steam turbine to generate electricity of $255.3 \mathrm{KW}$. In all, the waste plastic power plant generated a net power of $216.461 \mathrm{KW}$ at an equivalence ratio of 1.5 .
\end{abstract}

Keywords: Pyrolysis, HDPE, Simulation, Waste Plastic, Power Plant

\section{Introduction}

In this era of plastics dominated world, it remains a fact that there exists an ever increasing margin between the volume of waste plastics generated and the volume recycled [1]. Plastic waste is a major environmental problem that exist in millions of metric tonnes around the globe. With nearly 288 million tonnes of global plastic production per annum, plastic waste generates large landfilling problems and has environmental impact [2].

Plastics are polymer type of component with high molecular weight [3]. In 2007, the global High Density Polyethylene (HDPE) market reached a volume of more than 30 million tons. HDPE is known for its large strength to density ratio. The density of HDPE can range from 0.93 to $0.97 \mathrm{~g} / \mathrm{cm}^{3}$ or $970 \mathrm{~kg} / \mathrm{m}^{3}$ [4].
The plastic content of municipal solid waste represents about $9.5 \mathrm{wt} \%$ in the EU and about $11.7 \mathrm{wt} \%$ in the US [5], representing a major proportion of the post-consumer waste stream. There are six main plastics which arise in solid waste which are: High Density Polyethylene (HDPE), Low Density Polyethylene (LDPE), Polypropylene (PP), Polystyrene (PS), Polyvinyl Chloride (PVC) and Polyethylene Terephthalate (PET). The majority of waste plastic is disposed of with the mass of municipal solid waste through landfilling or incineration and the amount of plastic waste recycled is low, typically less than $10 \%$. Therefore, process routes which can treat the waste plastics and generate useful fuels or petrochemical feedstocks are generating increased interest. In addition, in many countries, waste plastic is collected as a separate waste fraction for ease of subsequent processing. Chemical recycling of the waste plastics, via pyrolysis and gasification, to generate useful hydrocarbons 
has been recognized as a promising technology [6].

Thermal cracking or Pyrolysis, involves the degradation of the polymeric materials by heating in the absence of oxygen. The process is usually conducted at temperatures between $350^{\circ} \mathrm{C}$ and $900^{\circ} \mathrm{C}$ and results in the formation of a carbonized char (solid residues) and a volatile fraction that may be separated into condensable hydrocarbon oil consisting of paraffins, isoparaffins, olefins, naphthenes and aromatics, and a noncondensable high calorific value gas. The proportion of each fraction and their precise composition depends primarily on the nature of the plastic waste but also on process conditions. The extent and the nature of these reactions depend both on the reaction temperature and also on the residence of the products in the reaction zone, an aspect that is primarily affected by the reactor design.

The main components of produced gases from pyrolysis of different types of plastic are methane, hydrogen, propane, propene, ethane, ethene and butane [7]. Only the pyrolysis of PVC produces hazardous chlorine gas [8]. Increase in process temperature increases the production of gases [9]. It is reported that $1 \mathrm{~kg}$ of plastic feedstock produces around 13 $26.9 \%$ gases by weight [8]. Therefore, the produced gases can be used in boiler for heating or in gas turbine for the generation of electricity without any flue gas treatment [10].

The Municipal Solid Waste (MSW) is one of the chronic environmental, health and economic problems in most developing countries [11]. MSW can be a valuable source of biomass, recycled materials, energy and revenue if properly and wisely managed [12]. However, many of the municipalities within the developing world do not have sufficient technical and economical capacities to treat and dispose MSW in an eco-friendly manner [13].

In many developing countries including Nigeria, consistent power supply remains an issue of concern. The technology of electricity generation from waste plastics if adopted and commercialized, can be a major player in the power sector

Waste Plastics can be converted into various forms of energy such as liquid-fuel oil, fuel gases, synthesis gas etc., which apart from curbing environmental concerns could be employed in electricity generation. This study focused on the pyrolysis of HDPE waste plastics to gaseous fuel for electricity generation. The methodology adopted here allows electricity to be generated from the combination of steam and gas turbines for proper energy optimization.

\section{Methodology}

In modelling and simulation of the waste plastic power plant, Aspen Hysys v10 was used. The Aspen Hysys model developed in this work was based on the original work of Mohamed et al. [14] for simulating a process that converts plastic waste to liquid fuel.

The following assumptions were made in developing the computer-based model:

i. Steady state process.

ii. The fuel used for heating is assumed to be heavy fuel oil.

iii. Char from pyrolysis contains only carbon.

iv. Major components of the fuel gas are ethylene, hydrogen, methane, ethane, propane, propene and nbutane

v. The turbine unit is modelled as a combustion reactor plus an expander

To develop the HDPE pyrolysis model, a conversion reactor was used to thermally crack the feed to produce volatile gas fuels at a temperature of about $400-500^{\circ} \mathrm{C}$, which was combusted in a Gibbs free energy reactor thereafter sent to a turbine (modelled as an expander) to generate electricity. Amazingly, the high temperature flue gas obtained from the expander after pressure loss was passed through a "Heat Recovery Steam Generator" that allowed water at $25^{\circ} \mathrm{C}$ to be heated up to produce steam which in turn drove a steam turbine to generate electricity.

HDPE exhibits a higher crystallinity, a higher melting point, and are completely volatilized at temperatures below $500^{\circ} \mathrm{C}[15]$.

The reaction equation:

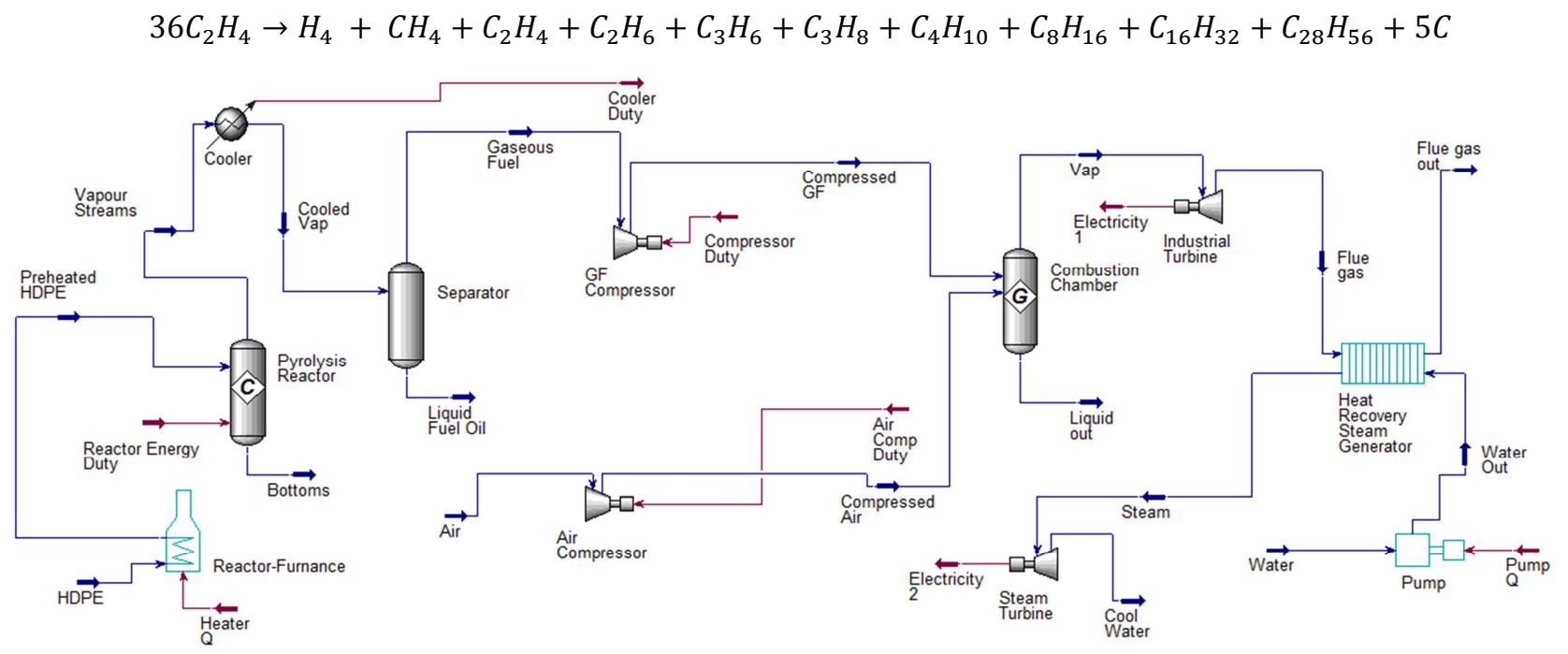

Figure 1. Aspen Hysys flow diagram of the waste plastic power plant. 


\subsection{Pyrolysis Reactor}

HDPE feed of $2000 \mathrm{~kg} / \mathrm{h}$ and at $25^{\circ} \mathrm{C}$ was preheated to a temperature of $180^{\circ} \mathrm{C}$ before entering the pyrolysis reactor modelled as a conversion reactor. The energy source for heating is supplied by the combustion of heavy fuel oil in a furnace. The pyrolysis reactor utilizes the heat from combustion of heavy fuel oil for heating of the HDPE feed.

\subsection{Separator}

The desired top product from the pyrolysis reactor was condensed by a cooler to a temperature of $200^{\circ} \mathrm{C}$ and sent to a separator that separated the liquid fuel oil from the desired gaseous fuel.

\subsection{Compressor}

Prior to combustion, the Gaseous fuel (GF) from the separator was pressurized by a compressor. Air modeled as $79 \%$ nitrogen and $21 \%$ oxygen was equally compressed to ensure adequate combustion to yield high temperature and pressured gas for the turbine.

\subsection{Combustion Chamber}

The combustion chamber is an important unit for the power generation from the pyrolysed gas. The gaseous fuel burned with excess air in the combustion chamber (modelled as a Gibb's free energy reactor) that produced a high temperature and pressured gas that drove the gas turbine

\subsection{Gas Turbine}

The industrial gas turbine utilized the high temperature and pressured effluent gas from the combustion chamber to achieve a mechanical work thereby generating electricity. The industrial gas turbine was modelled as an expander that generates electricity producing a high temperature flue gas as the exhaust gas from the gas turbine.

\subsection{Heat Recovery Steam Generator (HRSG)}

The flue gas from the gas turbine at atmospheric pressure still possessed a very high temperature which was recovered to drive a steam turbine. Heat recovery steam generator as the name implies is a special type of heat exchanger that utilizes the high temperature of the flue gas to heat up water at $25^{\circ} \mathrm{C}$ to produce steam. The flue gas passed through one side of the heat exchanger and the water at room temperature passed through the other to form steam. The following parameters were employed in modelling and simulation of the HRSG.

Table 1. HRSG simulation parameter [30].

\begin{tabular}{ll}
\hline Operating variables & Value \\
\hline Flue gas out & $200^{\circ} \mathrm{C}$ \\
Steam & $500^{\circ} \mathrm{C}$ \\
Water Out & $2500 \mathrm{KPa}$ \\
Tube passes & 2 \\
Shell passes & 2 \\
First pass & Counter \\
Shell type & $\mathrm{F}$ \\
\hline
\end{tabular}

\subsection{Steam Turbine}

The superheated steam from the HRSG drove the steam turbine modelled as an expander to generate the secondary electricity.

\section{Results and Discussion}

The Aspen Hysys model in this work for the pyrolysis process was based on the work of Mohamed et al. [14] for simulating a process that converts plastic waste to liquid fuel.

In order to evaluate the performance of the developed model, the results obtained from the simulation of the pyrolysis of waste plastics were compared with data available in the works of Kyong-Hwan [18] and Williams [19].

Table 2. Comparison of the yield of gas, liquid and char residue from the pyrolysis of waste HDPE.

\begin{tabular}{lll}
\hline Present Study & Kyong-Hwan Lee (2006) & P. T. Williams (2006) \\
\hline $\mathbf{4 5 0}^{\circ} \mathbf{C}$ & $\mathbf{4 3 0}^{\circ} \mathbf{C}$ & $\mathbf{4 5 0}^{\circ} \mathbf{C}$ \\
\hline Gas (wt $\%)$ & Gas (wt $\%)$ & Gas $\left(w t^{\%}\right.$ ) \\
38.7 & 20 & 13.0 \\
Liquid Fuel Oil (wt $\%)$ & Liquid Fuel Oil (wt $\%)$ & Liquid Fuel Oil (wt $\%)$ \\
55.5 & 75.5 & 84 \\
Char (wt $\%)$ & Char $(w t \%)$ & Char (wt $\%)$ \\
8.54 & 4.5 & 3 \\
\hline
\end{tabular}

The result presented in Table 2, shows the products from the pyrolysis reactor. The differences between the products yield from the pyrolysis reactor and those in the literature may be due to property variations and other factors taken into consideration during simulation but not properly reported by the source authors.
Aspen Hysys process simulator employed the law of conservation of mass to perform the material balances, based on the assumptions stated in Section 2.

A steady state process was assumed, therefore the accumulation term was zero. Also, since the process is entirely physical, mass inflow equals mass outflow. 
Table 3. Overall material balance.

\begin{tabular}{lllll}
\hline Rate of mass inflow & $\mathbf{K g} / \mathbf{h}$ & Reference & Rate of mass outflow & $\mathbf{K g} / \mathbf{h}$ \\
\hline HDPE Feed & 2000 & {$[16]$} & Bottoms & 172.8 \\
Air & 3000 & {$[17]$} & Liquid Fuel Oil & 1069 \\
Water & & Liquid Out & 0 \\
& 1475 & Cool water & 1475 \\
& & & Flue gas & 3758 \\
\hline
\end{tabular}

Table 4. Total energy balance.

\begin{tabular}{llllll}
\hline $\begin{array}{l}\text { Rate of energy inflow to the } \\
\text { system }\end{array}$ & $\mathbf{K J} / \mathbf{h}$ & $\begin{array}{l}\text { Rate of energy outflow from the } \\
\text { system }\end{array}$ & $\mathbf{K J} / \mathbf{h}$ & $\begin{array}{l}\text { Rate of energy generated within the system } \\
\text { (exothermic) }\end{array}$ & $\mathbf{K J} / \mathbf{h}$ \\
\hline Heater Q & $5.577 \mathrm{e} 5$ & Electricity 1 & $4.298 \mathrm{e} 6$ & Reactor Energy Duty \\
Cooler Duty & $1.533 \mathrm{e} 6$ & Electricity 2 & $9.190 \mathrm{e} 5$ & & \\
Air Comp Duty & $1.786 \mathrm{e} 6$ & & & & \\
Compressor Duty & $2.767 \mathrm{e} 5$ & & & \\
Pump Q & 4685 & & & \\
\hline
\end{tabular}

Table 4 shows the calculated values of various process parameters after simulation. The net power from the plant was $216.461 \mathrm{KW}$ after subtracting the utility power requirement for heating, cooling, pumping and compressing gas. The plant was able to produce $216.461 \mathrm{KW}$ from $2000 \mathrm{~kg} / \mathrm{h}$ of HDPE feed.

The plant was operated at an equivalence ratio of 1.5 . The power generated from the gas turbine was significantly greater than that generated from steam turbine, as process conditions for running the steam turbine depends wholly on the resulting temperature of the flue gas from the gas turbine. The gaseous fuel and compressed air had an equivalent amount of pressure after compression prior to combustion.

Table 5. Simulation results.

\begin{tabular}{ll}
\hline Parameters & Values \\
\hline Cooled vapour temperature $\left({ }^{\circ} \mathrm{C}\right)$ & 200 \\
Steam temperature $\left({ }^{\circ} \mathrm{C}\right)$ & 500 \\
Compressed air pressure $(\mathrm{KPa})$ & 2500 \\
Air mass flow rate $(\mathrm{Kg} / \mathrm{h})$ & 3000 \\
HDPE mass flow rate $(\mathrm{Kg} / \mathrm{h})$ & 2000 \\
Gaseous fuel mass flow $(\mathrm{Kg} / \mathrm{h})$ & 758.3 \\
Liquid fuel oil mass flow $(\mathrm{Kg} / \mathrm{h})$ & 1069 \\
Bottoms mass flow $(\mathrm{Kg} / \mathrm{h})$ & 172.8 \\
Equivalence ratio & 1.5 \\
Electricity 1 - Power $(\mathrm{KW})$ & 1194 \\
Electricity 2 - Power $(\mathrm{KW})$ & 255.3 \\
Heater Q - Power $(\mathrm{KW})$ & 154.9 \\
Cooler duty - Power $(\mathrm{KW})$ & 425.9 \\
Compressor duty - Power $(\mathrm{KW})$ & 76.86 \\
Air comp duty - Power $(\mathrm{KW})$ & 496.2 \\
Pump Q - Power $(\mathrm{KW})$ & 1.301 \\
Net Power $(\mathrm{KW})$ & 216.461 \\
\hline
\end{tabular}

Conversion efficiency is the ability of the conversion reactor to convert waste plastic into vapour. The pyrolysis reactor produced a small percentage of char with $8.54 \%$. The composition of the char is $100 \%$ carbon.

The mass flow rate of the char was calculated as 172.87 $\mathrm{Kg} / \mathrm{h}$ bottom product from the pyrolysis reactor. The desired top product from the pyrolysis reactor (a mixture of the liquid fuel oil and gaseous fuel) has a mass flow rate of $1827 \mathrm{~kg} / \mathrm{h}$.
After cooling of the top product and separation to obtain the gaseous fuel from the liquid fuel oil, their mass flow rate was calculated as $758.3 \mathrm{Kg} / \mathrm{h}$ and $1069 \mathrm{Kg} / \mathrm{h}$ respectively, with a corresponding percentage conversion of $38.7 \%$ and $53.5 \%$. The pyrolysis reactor simulated at $450^{\circ} \mathrm{C}$ utilized heavy fuel oil as the energy source generating an exothermic heat energy of $-4.576 \mathrm{e} 6 \mathrm{KJ} / \mathrm{h}$. The reactor's energy duty and the heater duty are the total energy requirements for the pyrolysis reactor.

\section{Conclusion and Recommendations}

This study developed a steady state computer-based model using Aspen Hysys v10 process simulator for the pyrolysis of waste plastics to generate electricity. The developed model was simulated for different operating conditions based on parameter values available in the literature. The plant utilized HDPE plastic feed to generate gaseous fuel product from the pyrolysis reactor that drove gas and steam turbines, producing a net power of $216.461 \mathrm{KW}$

Due to the unavailability of data from a real life waste plastic power plant, the performance of the developed model was evaluated up to the point of flue gas generation by comparing the simulation results with data obtained from the literature. This study provides a theoretical framework for waste plastic power plant using HDPE as the feed. Though the performance of the computer based model has been evaluated, the results require further study in order to improve the model of the waste plastic power plant. For future work, the following recommendations are made:

i. To model a plant that utilizes multiple waste plastic feed to generate electricity

ii. Modelling a fluidized bed as the pyrolysis reactor that utilizes steam as the heating energy

iii. A kinetic reaction model based on reaction mechanisms needs to be established to predict the pyrolysis products with respect to feedstock composition and reaction operating conditions 


\section{References}

[1] Mastellone, M. L., Arena, U., Barbato, G., Carrillo, C., Romeo, E., \& Granata, S. (2006). A Preliminary Modeling Study of a Fluidized Bed Pyrolyzer for Plastic Wastes. Paper Presented at the 29th Meeting on Combustion. Pisa, Italy: Italian Section of the Combustion Institute.

[2] Aguado, R. (2014). Principal Component Analysis for Kinetic Scheme Proposal in the Thermal Pyrolysis of Waste HDPE Plastics. Chemical Engineering Journal, 3, 264-290.

[3] Yamada, H., Mori, H., \& Tagawa, T. (2010). CO2 Reforming of Waste Plastic. Journal of Industrial and Engineering Chemistry (16), 7-9.

[4] James, L. W., David, D. (2005). Polyolefins: Processing, Structure Development and Properties. Munich: Hanser Verlag. ISBN 1569903697.

[5] Wu, C., \& Williams, P. (2008). Effects of Gasification Temperature and Catalyst Ratio on Hydrogen Production from Catalytic Steam Pyrolysis-Gasification of Polypropylene. In Energy \& Fuels (pp. 4125-4132). Boston: Environ International.

[6] Slaney, E., \& Williams, P. T. (2007). Analysis of Products from the Pyrolysis and Liquefaction of Single Plastics and Waste Plastics Mixtures. Resources Conservation Recycling.

[7] Williams, P. T., \& Williams, E. A. (1998). Interaction of Plastics in Mixed-Plastics Pyrolysis. Energy Fuel, 188-196.

[8] Chen, D., \& G, Y. (2014). High Efficiency Chlorine Removal from Polyvinyl Chloride (PVC) pyrolysis with a Gas-Liquid Fluidized Bed Reactor. Elsevier, Waste Management, 10451050 .

[9] Lopez, A. (2011). Dechlorination of Fuels in Pyrolysis of PVC Containing Plastic Wastes. Elsevier, Fuel Processing Technology.

[10] Conesa, J. A., Font, R., Gomis, A., \& Garcia, N. (1994). Pyrolysis of Polyethylene in a Fluidized Bed Reactor. Energy \& Fuels, 8 (6), 112-121.

[11] Nizami, A., Shahzad, K., Rehan, M., Khan, M., Almebi, T., Basahi, J., \& Demirbas, A. (2016). Developing Waste Biorefinery in Makkah. Saudi Arabia: Applied Energy.

[12] Miandad, R., Rehan, M., Ouda, O. K., Khan, M. Z., Ismail, I. M., Shahzad, K., \& Nizami, A. S. (2016a). Waste-toHydrogen Energy in Saudi Arabia: Challenges and Pespectives, BioHydrogen Production. Sustainability of Current Technology and Future Perspective.

[13] Tacoli, C. (2012). Urbanization, Gender and Urban Poverty: Paid Work and Unpaid Care Work in the City. Population and Development Branch, Human Settlements Group, UNFPA.

[14] Mohamed, G. A., Ahmed, I. A., \& Babiker, K. A. (2014). Conversion of Plastic Waste to Liquid Fuel. International Journal of Technical Research and Applications, 2 (3), 29-31.

[15] Mohamed, A. (2016). Utilization of Thermal Plasma for Conversion of Thermoplastic Waste to oil Products in a Pyrolysis Reaction. M.Sc. University of Ontario Institute of Technology.
[16] Hussian, H. J., \& Sebzali, M. J. (2016). Modelling of Municipal Solid Waste Incineration Plant for Electricity Generation in Kuwait. International Journal of Sustainable Water and Environmental Systems, 8 (2), 65-69.

[17] AbdAllah, M. M., Mohammed, E. M., Tawfiag, A. J., Alaaeldin, Abdalrahim, \& Hamdnalla. (2016). Thermodynamics Optimization of GARRI (1) Combined Cycle Power Plant by using Aspen Hysys Simulation. International Journal on Recent and Innovation Trendsin Computer and Communications, 4 (1), 69-78.

[18] Kyong-Hwan, L. (2006). Thermal and Catalytic Degradation of Waste HDPE. In J. Scheirs, \& W. Kaminsky (Eds.), Feedstock Recycling and Pyrolysis of Wsate Plastics (pp. 129160). New York: John Wiley \& Sons, Ltd.

[19] Williams, P. T. (2006). Yield and Compositions of Gases and Oils/Waxes from the Feedstock Recycling of Waste Plastic. In J. Scheirs, \& W. Kaminsky (Eds.), Feedstock Recycling and Pyrolysis of Waste Plastics (pp. 286-313). New York: John Wiley \& Sons, Ltd.

[20] Kaminsky, W., \& Sinn, H. (1996). Recycling and Recovery of Plastics. In B. M. Brandrup, \& G. J. Menges (Eds.). Munich: Hansen.

[21] Achimnole, E. N., orhorhoro, E. K., \& Onogbotsere, M. O. (2017). Simulation of Gas Turbine Power Plant using High Pressure Fogging Air Intake Cooling System. International Journal of Emerging Engineering Research and Technology, 5 (5), 16-23.

[22] Ashworth, D., Elliot, P., \& Toledano, M. (2014). Waste Incineration and Adverse Birth and Neonatal Outcomes. A Sysytematic Review, 69, 120-132.

[23] Blazso, M. (2004). Plenary Lecture, 16th International Symposium on Analytical and Applied Pyrolysis. Alicante.

[24] Bockhorn, H., Hornung, A., \& Hornung, U. (1999). Journal of Analytical and Applied Pyrolysis, 48, 93-109.

[25] Ekwonu, M. C., Perry, S., \& Oyedoh, E. A. (2013). Modelling and Simulation of Gas Engines using Aspen Hysys. Journal of Engineering Science and Technology Review, 6 (3), 1-4.

[26] Fontana, A., Braekman-Danheux, C., \& Laurent, P. (1998). Gasification, the Gateway to a Cleaner Future. Dresden: Ichem Meeting.

[27] Gabauer, M. S. (1996). Recycling and Recovery of Plastics. In B. M. Brandrup, \& J. G. Menges (Eds.). Munich: Hansen.

[28] Gisele, J. C., \& Andre, F. (2006). Production of Gaseous and Liquid Fuels by Pyrolysis and Gasification of Plastics: Technological Approach. In J. Scheirs, \& W. Kaminsky (Eds.), Feedstock Recycling and Pyrolysis of Waste Plastics (pp. 251-283). New York: John Wiley \& Sons, Ltd.

[29] Harsha, R. T., Aman, S., Vaibhav, A., \& Suarabh, K. (2016). Fabrication and Analysis of a Mechanical System to Convert Waste Plastic into Crude Oil. International Journal of Emerging Technology and Advanced Engineering, 6 (1), 212214.

[30] Jose, M. R. (2018). Simulation of a Gas Power Plant. Norwegian University of Science and Technology. 